\title{
Innovation Capacity and Economic Development
}

\author{
China and India
}

\author{
Peilei Fan*
}

March 2008

\begin{abstract}
Both China and India, the emerging giants in Asia, have achieved significant economic development in recent years. China has enjoyed a high annual GDP growth rate of 10 per cent and India has achieved an annual GDP growth rate of 6 per cent since 1981. Decomposing China and India's GDP growth from 1981 to 2004 into the three factors' contribution reveals that technology has contributed significantly to both countries' GDP growth, especially in the 1990s. R\&D outputs (high-tech exports, service exports, and certified patents from USPTO) and inputs ( $R \& D$ expenditure and human resources) further indicate that both countries have been very committed to $R \& D$ and their output is quite efficient.

Both governments have played an essential role in transforming their national innovation systems so that they can be more adaptable to economic development. The main focus of their reforms has been to link the science sector with the business sector and to provide incentives for innovation activities. Balancing import of technology and indigenous R\&D effort is another major theme. Innovation capability development has become more and more critical to the success of biofirms in India and China. Institutional factors have great influence on choice of innovation at the firm level, i.e., the decision at firm level in terms of indigenous R\&D or import of technology. Nevertheless, limited financial resources and insufficiently qualified human resources remain two major challenges for domestic companies in both countries.
\end{abstract}

Keywords: China, India, innovation capability, domestic companies, ICT, biotech

JEL classification: O31, O3, L65

Copyright @ UNU-WIDER 2008

* Michigan State University, East Lansing; email: fanpeile@msu.edu

This study has been prepared within the UNU-WIDER project on the Southern Engines of Global Growth.

UNU-WIDER acknowledges the financial contributions to the research programme by the governments of Denmark (Royal Ministry of Foreign Affairs), Finland (Ministry for Foreign Affairs), Norway (Royal Ministry of Foreign Affairs), Sweden (Swedish International Development Cooperation Agency—Sida) and the United Kingdom (Department for International Development). 


\section{Acronyms}

IP intellectual property

IRIs industrial research institutes

MNCs multinational corporations

NDRC National Development and Reform Commission (of China)

NIEs newly industrialized economies

NIS national innovation system

PE private equity

R\&D research and development

S\&T science and technology

SEZs special economic zones

TFP total factor productivity

TRIPS Agreement on Trade-related Aspects of Intellectual Property Rights

TVEs township and village enterprises

TPS Technology Policy State

USPTO United States Patent and Trademark Office

VC venture capital

WIPO World Intellectual Property Organization

The World Institute for Development Economics Research (WIDER) was established by the United Nations University (UNU) as its first research and training centre and started work in Helsinki, Finland in 1985. The Institute undertakes applied research and policy analysis on structural changes affecting the developing and transitional economies, provides a forum for the advocacy of policies leading to robust, equitable and environmentally sustainable growth, and promotes capacity strengthening and training in the field of economic and social policy making. Work is carried out by staff researchers and visiting scholars in Helsinki and through networks of collaborating scholars and institutions around the world.

www.wider.unu.edu

publications@wider.unu.edu

UNU World Institute for Development Economics Research (UNU-WIDER)

Katajanokanlaituri 6 B, 00160 Helsinki, Finland

Typescript prepared by Liisa Roponen at UNU-WIDER

The views expressed in this publication are those of the author(s). Publication does not imply endorsement by the Institute or the United Nations University, nor by the programme/project sponsors, of any of the views expressed. 


\section{Introduction}

China and India, the two emerging giants in Asia, have achieved impressive economic growth since the beginning of 1980s. From 1981 to 2004, China enjoyed a high annual GDP growth rate of 10 per cent and India achieved an annual GDP growth rate of 6 per cent. As the nation with the largest population of 1.3 billion, China reached a nominal GDP of US\$2.68 trillion and was the fourth largest economy in the world after the US, Japan, and Germany in 2006 (China Daily 2007). After China, India is the second-most populous nation with almost 1.1 billion people. It achieved US $\$ 0.92$ billion of nominal GDP in 2006 and thus placed itself as the 12th largest economy in the world; but rose to the third largest when measured at purchasing power parity exchange rate (The Economist 2007).

In today's knowledge economy, innovation capability has been critical to national economic growth (Porter 1990; Nelson 1993). What has not been emphasized is the fact that this not only refers to developed countries and those who caught up earlier such as Japan, and the newly industrialized economies (NIEs), but also developing countries, such as China and India.

Some have argued that China's and India's growth is due to advantages in the abundance of low-cost production factors such as labour and land, in addition to the foreign investment and technology resulting from the economic reforms that liberalized markets in China and India. This is similar to the 'accumulation' theory of growth held by a camp of scholars who contribute the high growth of NIEs, i.e., South Korea, Taiwan, Hong Kong, and Singapore, to high savings and investment, and argue that these factors have made it possible for the NIEs to better utilize the technology inherited from the world's leaders in this field (Krugman 1994; Young 1995; Collins and Bosworth 1996).

Some emphasize the role of technology progress in economic development and have documented how the transformation of national innovation systems and certain government technology policies have promoted indigenous R\&D in China and India. (Liu and White 2001; Katrak 2002; Kumar and Jain 2002; Fan 2006a; Fan and Watanabe 2006; Motohashi and Yun 2007). This is an echo of the 'assimilation' theory, which asserts that the productivity growth resulting from the learning, entrepreneurship and innovation has been the critical source of NIEs' growth (Dahlman 1994; Hobday 1995; Kim 1998).

In this paper, I intend to investigate how innovation capability has become the critical driving force for economic development in China and India. To achieve this objective, I first assess in section 2 the contribution of technology progress to economic development for both countries from 1981 to 2004. Then section 3 analyses the policy measures behind the numbers, with a focus on the transformation of the national innovation systems in China and India. In Section 4, using an example from the biotech

industry, I examine at the micro level how vital has innovation capacity been to the growth of domestic companies and the main challenges faced by these in developing innovation capabilities; section 5 concludes.

With a combined population of 2.4 billion, economic growth in China and India has profound meaning for the rest of the world. If they can repeat the growth miracle of the NIEs, the much smaller economies in East Asia, not only can China and India eradicate 
a large proportion of the world's poverty, but they can also provide great policy implications for other developing countries. Despite differences in growth rate, growth pattern, and fast growing sectors, China and India share similarities in terms of their large population base and economic growth since the 1980s. Moreover, they both experienced the transition from planned economy to market-oriented economy. Both governments are committed to economic growth as well as to promoting indigenous capability. In this paper, I focus on the innovation capability perspective in order to provide insights for policymakers wanting to use innovation capability, particularly that originating in the developing countries, as the instrument for economic growth. It is hoped that more developing countries can benefit from the experience of China and India, as well as from the growth process of the well-studied NIEs.

\section{Contribution of technology progress to economic development}

\subsection{Economic development of China and India}

Since the independence of China and India, both in the 1940s, these countries have utilized new ideologies to foster their growth: communism in China and Fabian socialism in India (Lal 1995). Shortly after the establishment of the People's Republic of China in 1949, the country adopted a socialist heavy-industry development strategy. The government took control of a large part of the economy and set up new industries, and it would appear that China grew faster than India until the end of 1970s (Lal 1995). For instance, according to World Bank data (2006), China's GDP per capita growth rate reached 2.9 per cent per annum during the years 1960-80, despite the disruption of the Great Culture Revolution. China's explosive economic growth took off after economic reform was launched in 1978 by Deng Xiaoping.

Figure 1

Economic development in China and India, 1960-2005

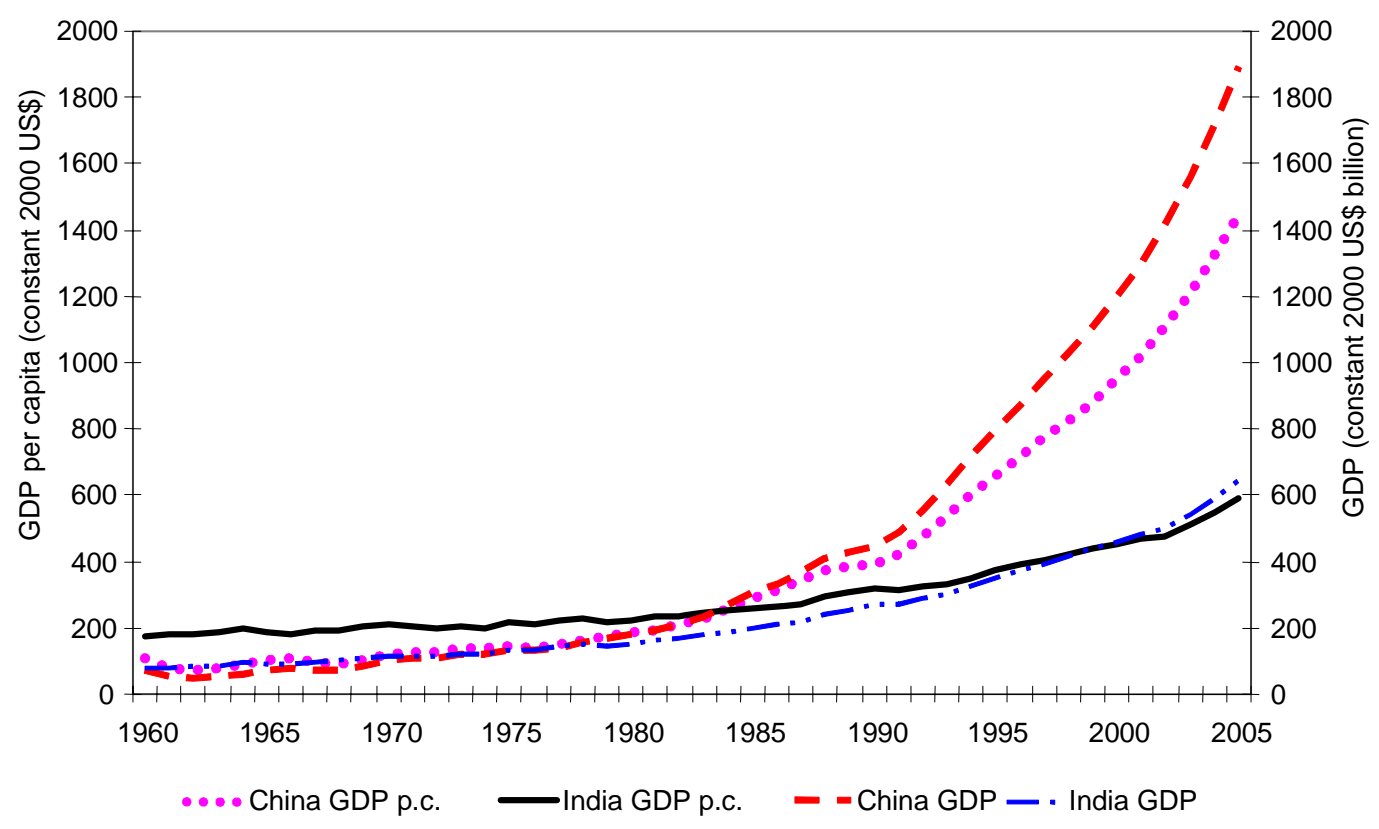

Source: World Bank (2006). 
Following the successful reform of the agriculture sector with the dismantling the communes and the introduction of the household responsibility system at the end of 1970s, the government encouraged other types of activities such as setting up township and village enterprises (TVEs), facilitated foreign direct investment, and enhanced the link to the world economy through trade and import of foreign technologies. The government formally announced in 1993 that the goal of the reform was to establish a socialist market economy and to set up special economic zones (SEZs). Triggered by this and the foreign capital it attracted as well as other policy measures, the economy experienced a second surge in the early 1990s. In 2001, China's membership in the WTO spurred another large inflow of foreign capital in subsequent years. Overall, annual GDP per capita growth rate was at a high 8.3 per cent from 1980 to 2005 (Figure 1).

After independence in 1947, Indian leaders introduced economic policies that were characterized by import substitution, industrialization, state intervention in labour and financial markets, a large public sector, business regulation and central planning. Nevertheless, India's protectionism bordered rather on Fabian socialism and was less extreme than the Soviet style central-command system in China, as the regime involved both public and private sectors and was based on direct and indirect state intervention (Lal 1995). The low economic growth from 1947 to 1980, however, did not meet the expectations of the country's leaders: annual growth rate of GDP per capita was a low 1.1 per cent during 1960-80 (Figure 1). The high 3.7 per cent annual growth rate for GDP per capita for the period 1980-2005 can be attributed to two stages of reforms: the pro-business measure initiated by Rajiv Gandhi in 1980 and economic liberalization initiated in 1991 by Prime Minister P. V. Narashimha Rao and his finance minister, Manmohan Singh.

\subsection{The contribution of technology progress to economic growth}

Technology progress has contributed significantly to the expansion of GDP, especially in the 1990s, for both China and India (Figure 2). GDP growth rate is widely acknowledged as the indicator of the speed of economic development. China has enjoyed an annual GDP growth rate of 9.6 per cent since 1981, while India has achieved a corresponding figure of 5.6 per cent. GDP growth rate can be decomposed into three parts: the contributions of capital, labour, and technology, and the share of technology can be measured by total factor productivity (TFP) growth rate. 1 Japan, for instance, had a very high TFP growth rate during its peak growth period during the decades of the 1960 s to the 1980 s.

Decomposing China and India's GDP growth into the three factor contributions reveals that technology has significantly influenced both countries' economic development in the 1990s. However, from 2001 to 2004, the contribution from technology progress to India's economic development diminished to a marginal position.

At the beginning of China's reform era (1981-85), capital was the leading factor for growth, influencing GDP growth at 4.5 per cent annually, while technology promoted

1 For a detailed explanation on the TFP calculations, refer to Fan and Watanabe (2006). 
Figure 2

Contribution of technological progress to economic growth in China and India, 1981-2004

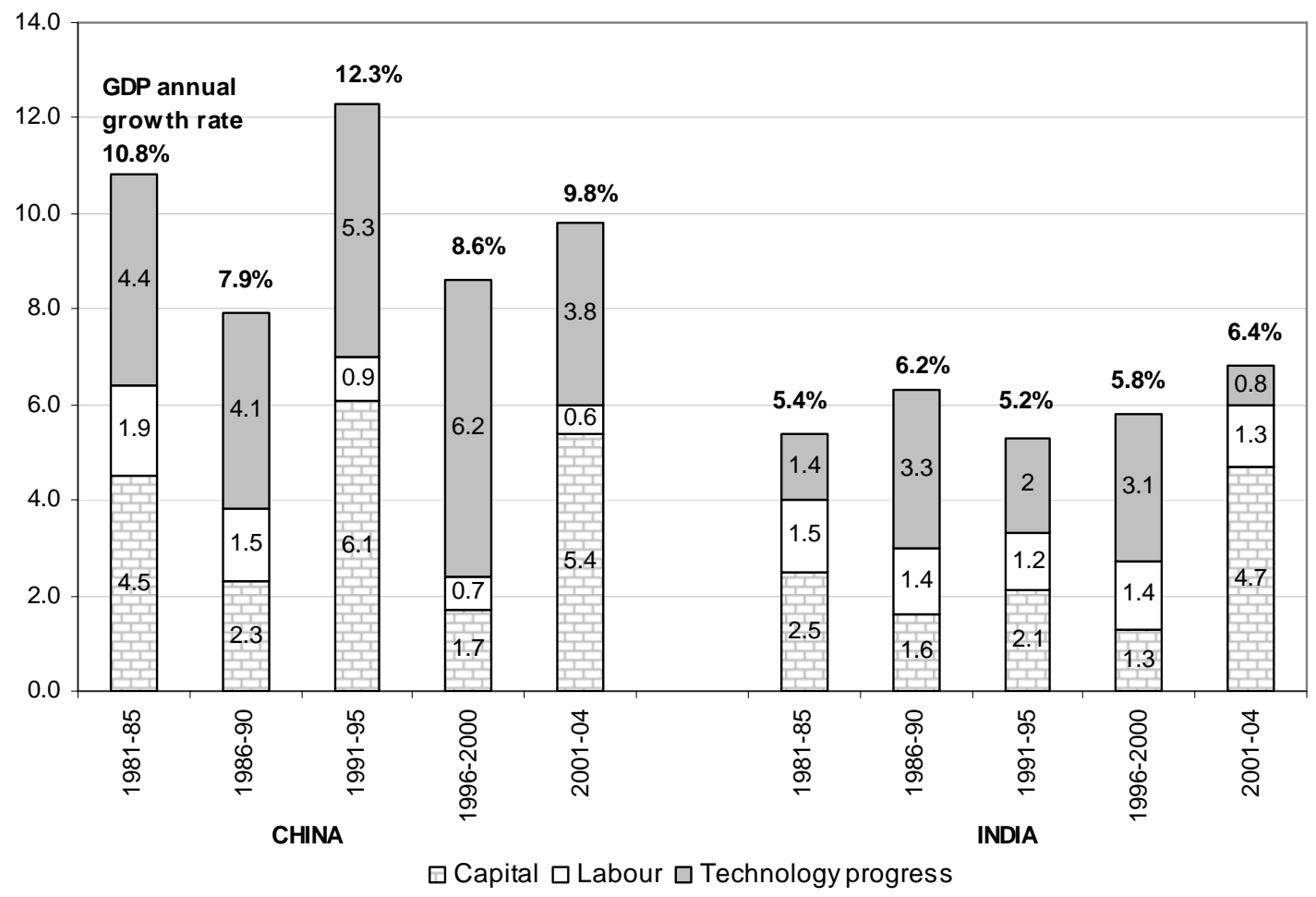

Source: Computed by the author based on World Bank (2006) data.

GDP growth by 3.9 per cent per annum. However, from 1986 to 2000, technology progress became the leading production factor, contributing to half of the GDP growth. In 2001-04, although a large injection of capital triggered a 9.8 per cent growth in GDP, the share of technological progress to GDP nevertheless was still 3.8 per cent per annum. It should also be noted that labour's contribution to growth has decreased over time. The share of capital was the lowest during 1996-2000, corresponding to the outbreak of the Asian financial crisis of that period.

At the start of the reform era (1981-85) in India, capital, labour, and technology contributed to economic growth in a descending order, as indicated by their GDP growth rate contributions of 2.5 per cent, 1.5 per cent, and 1.4 per cent, respectively. However, similarly to China, the leading contributor to GDP growth was technology from 1986 to 2000, except for the years 1991-95 when technology was slightly behind that of capital. But from 2001 to 2004, the contribution from technology progress dropped to a marginal position, as its share in GDP growth was only 1.5 per cent annually. This was a sharp contrast to the contribution of capital that caused the 3.5 per cent GDP growth rate per annum. Unlike China, labour has a quite important role to play in India's economic growth, as it consistently caused GDP to grow from 1.2 per cent to 1.5 per cent.

\subsection{Export of knowledge products and patent}

High-tech export-being a direct indicator of the economic benefit derived from technology progress in the global market-is appropriate for measuring China and India's knowledge economy. In 1992 high-tech exports accounted for 5 per cent of the country's overall exports and less than 1 per cent of GDP. By 2004, revenue from high- 
tech exports had reached US\$163 billion and accounted for over 25 per cent and 8.4 per cent of total exports and GDP, respectively (World Bank 2006). According to Wu Yi, China's Vice Premier, the country's policy of 'enhancing trade by relying on science and technology' had led to the rapid expansion of exports (Asia News 2004). In contrast to China's impressive high-tech exports, India increased its exports in this field from 0.1 per cent of GDP in 1988 to only 0.4 per cent in 2005 (World Bank 2006). However, if we take account the fact that software services, a strong sector in India, were not considered as high-tech exports but rather as service exports, performance is also impressive: service exports grew from 0.9 per cent of GDP in 1975 to 3.9 per cent of GDP in 2004, a pace much faster than China. Figure 3 indicates that China outperforms in manufacturing while India excels in service.

The number of granted patents is an important indicator of a nation's innovation capability. Because the registration of patents from different offices such as China's and India's are not comparable in terms of approval requirements, using US patent data can provide some base line for comparison. During 1970-99, inventors based in China and

Figure 3

High tech and service exports as a percentage of GDP

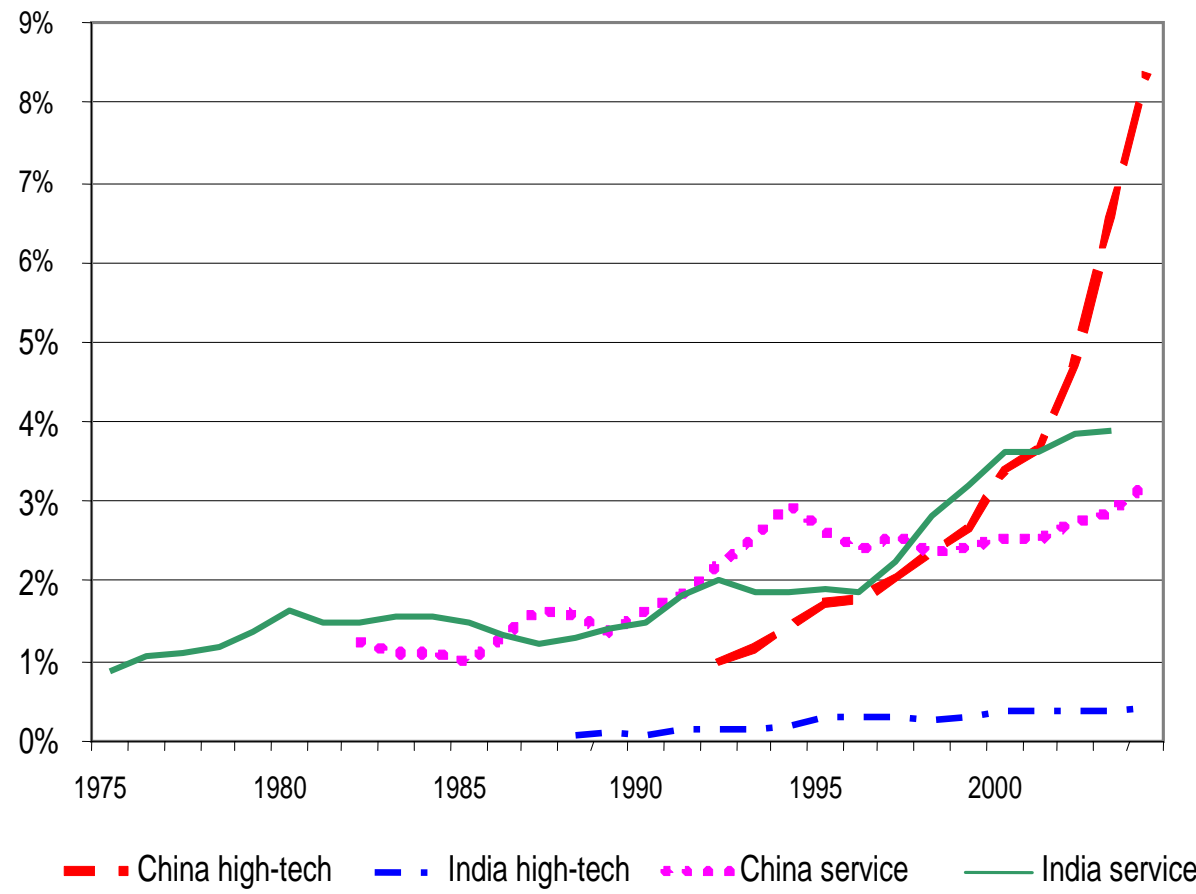

Source: World Bank (2006).

Table 1

US patents granted to Asian inventors, 1970-99

\begin{tabular}{lrrrrrrr}
\hline Recipient countries & $1970-74$ & $1975-79$ & $1980-84$ & $1985-89$ & $1990-94$ & $1995-99$ & Total 1970-99 \\
\hline Taiwan & 1 & 176 & 397 & 1,772 & 5,271 & 12,366 & 19,983 \\
South Korea & 24 & 43 & 91 & 424 & 2,890 & 11,366 & 14,838 \\
Hong Kong & 59 & 75 & 113 & 177 & 279 & 570 & 1,273 \\
Singapore & 21 & 9 & 20 & 47 & 148 & 499 & 744 \\
China & 61 & 2 & 7 & 129 & 239 & 332 & 770 \\
India & 83 & 67 & 40 & 64 & 126 & 316 & 696 \\
\hline
\end{tabular}

Source: Adapted from (Mahmood and Singh 2003: 1034). 
India were granted 770 and 696 patents, respectively, by the US Patent Office. Though the number of approvals is still far behind Taiwan and South Korea, they are quite comparable to Hong Kong and Singapore (Table 1). Forty-four of the 50 top patent winners in China represent domestic firms or organizations, while about 30 out of India's 50 top patent winners are foreign multinationals or organizations (Mahmood and Singh 2003). However, the situation seems to be improving, as only15 per cent of patents during 1990-2001 went to foreign affiliates located in India (Mani 2004). Table 1 indicates the trend in patent activities for both countries.

\subsection{Knowledge input}

It is widely acknowledged that financial investment and human resources in R\&D are two important input factors for building up the innovation capability of a nation.

China and India have invested heavily in R\&D. This is true particularly for China since the mid-1990s; R\&D expenditure as a percentage of GDP increased from around 0.6 per cent in 1996 to 1.44 per cent in 2004. This is still behind the expenditures of the developed countries that spend on average 2-3 per cent of GDP on R\&D. Nevertheless, China's progress is impressive, considering that R\&D expenditures increased even faster than its economy, which achieved an annual GDP growth rate of approximately 910 per cent during the same period. Since 2003 China has had the third largest R\&D expenditures (totalling US\$108.9 million) after US (US\$301.5 million) and Japan (US\$119.8 million) (China Net 2003). According to OECD, China surpassed Japan in 2006 and became the second largest nation in R\&D expenditure with US\$136 billion (China Gate 2006) (Figure 4)

In 1990 India spent around 0.7 per cent of its GDP on R\&D; in 2004, the figure was 0.69 per cent. This means that India's R\&D has expenditure increased at the same pace as its economy, which has enjoyed a high annual GDP growth rate of 5.9 per cent since 1980. For instance, during the year 2004-05 India spent US\$5.38 billion (Figure 4).

It is worth mentioning that the contributions of the business sector to $R \& D$ expenditure are drastically different in China and India. Over 60 per cent of China's R\&D expenditure originates from business enterprises ( $R \& D$ Magazine 2005). Enterprises contribution in India is only marginally: in 2003, over 70 per cent of the R\&D expenditure was from central or state governments; enterprises accounted for a mere 25 per cent (GoI 2006).

Both China and India lead in $R \& D$ human resources with respect to absolute numbers. However, in terms of R\&D researchers per 1,000 people, China (7.08) and India are both below 10 and in a lower category in comparison to OECD countries and other NIEs such as South Korea and Singapore or the emerging economies of Brazil, Cuba, Hungary, Philippines and Russian Federation (Figure 5).

Nevertheless, the large population bases of these countries imply that China and India have an advantage in R\&D human resources. In fact, the attraction of a rich reserve of R\&D human resources has encouraged multinational corporations to locate their corporate research centres in both countries. According to China's National Research 
Figure 4A

China's R\&D expenditure and a percentage of GDP

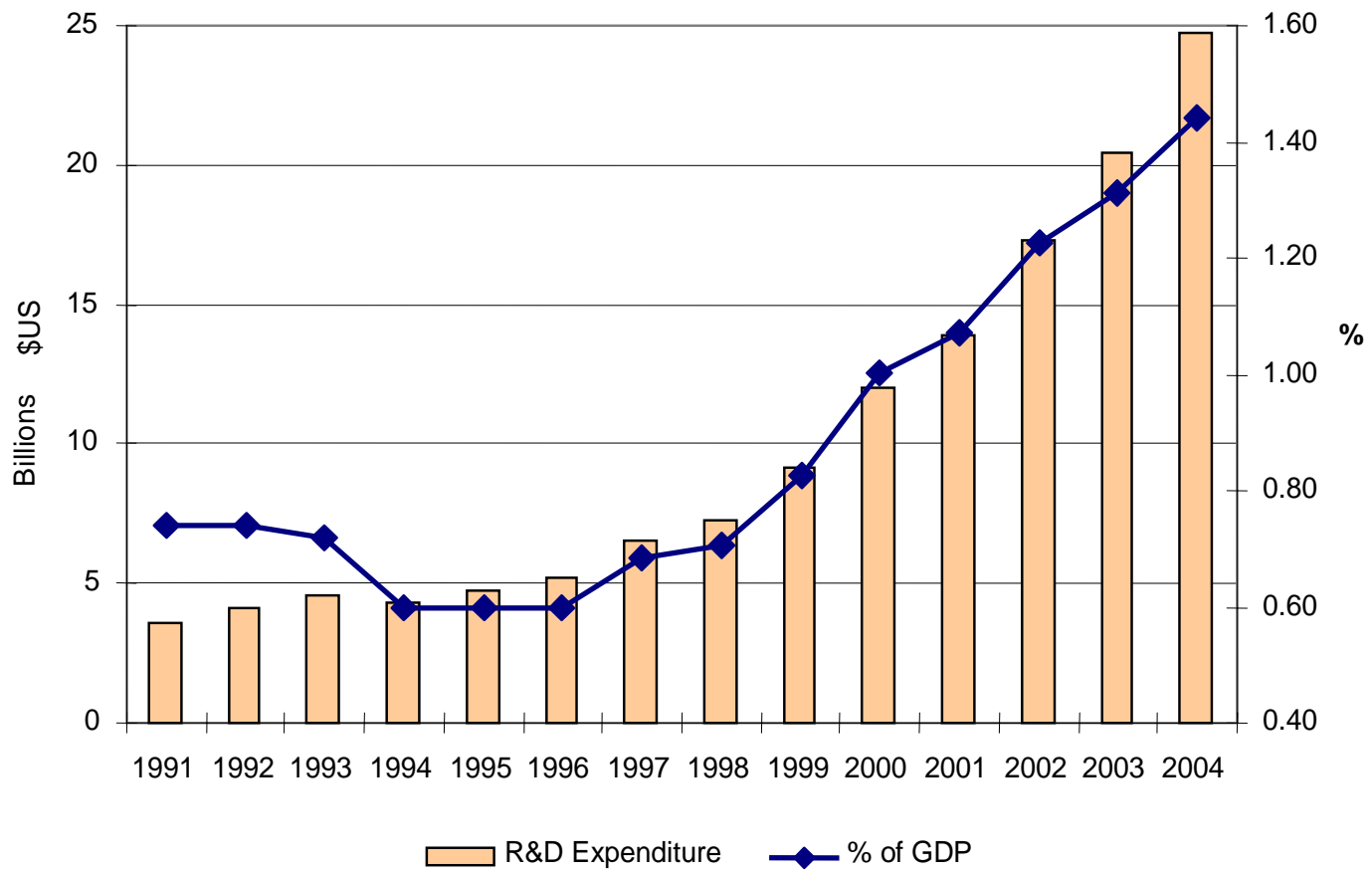

Source: World Bank (2004, 2006).

Figure 4B

India's $R \& D$ expenditure and its percentage of GDP

Rs. Crores

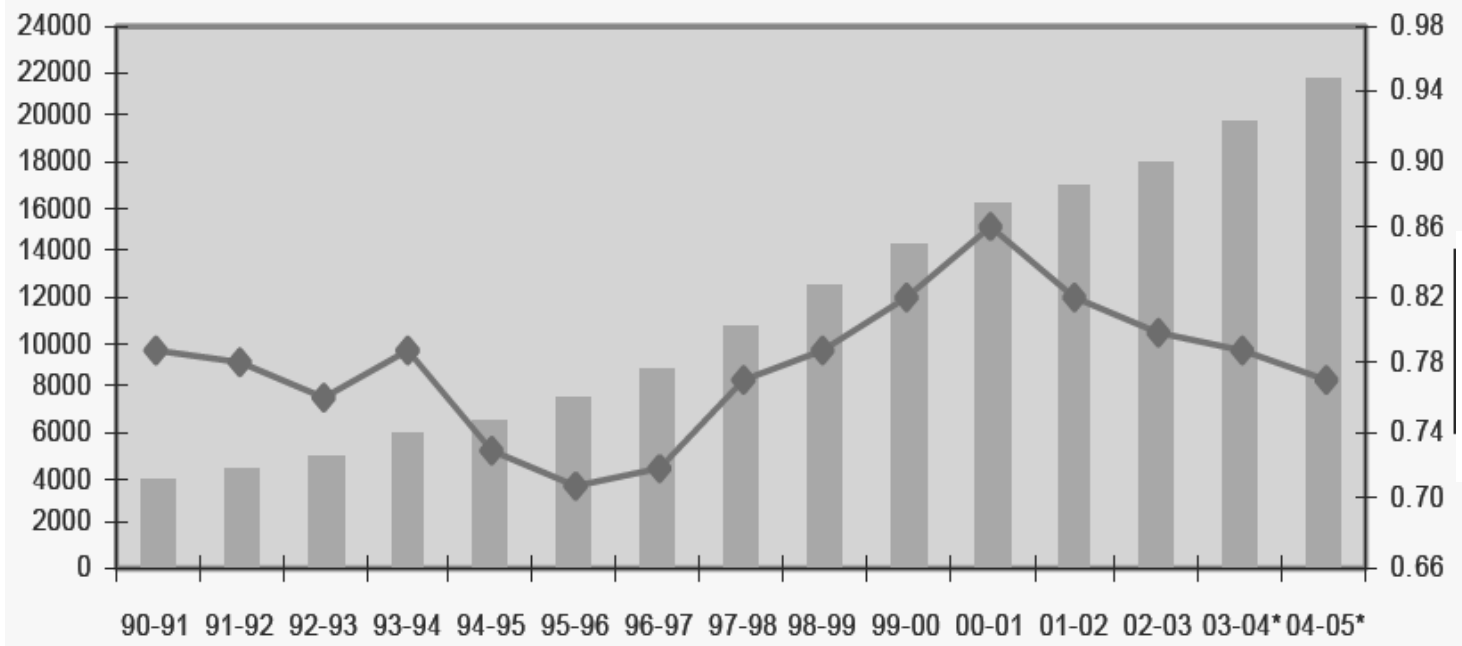

YEARS

Source: Gol (2005). 


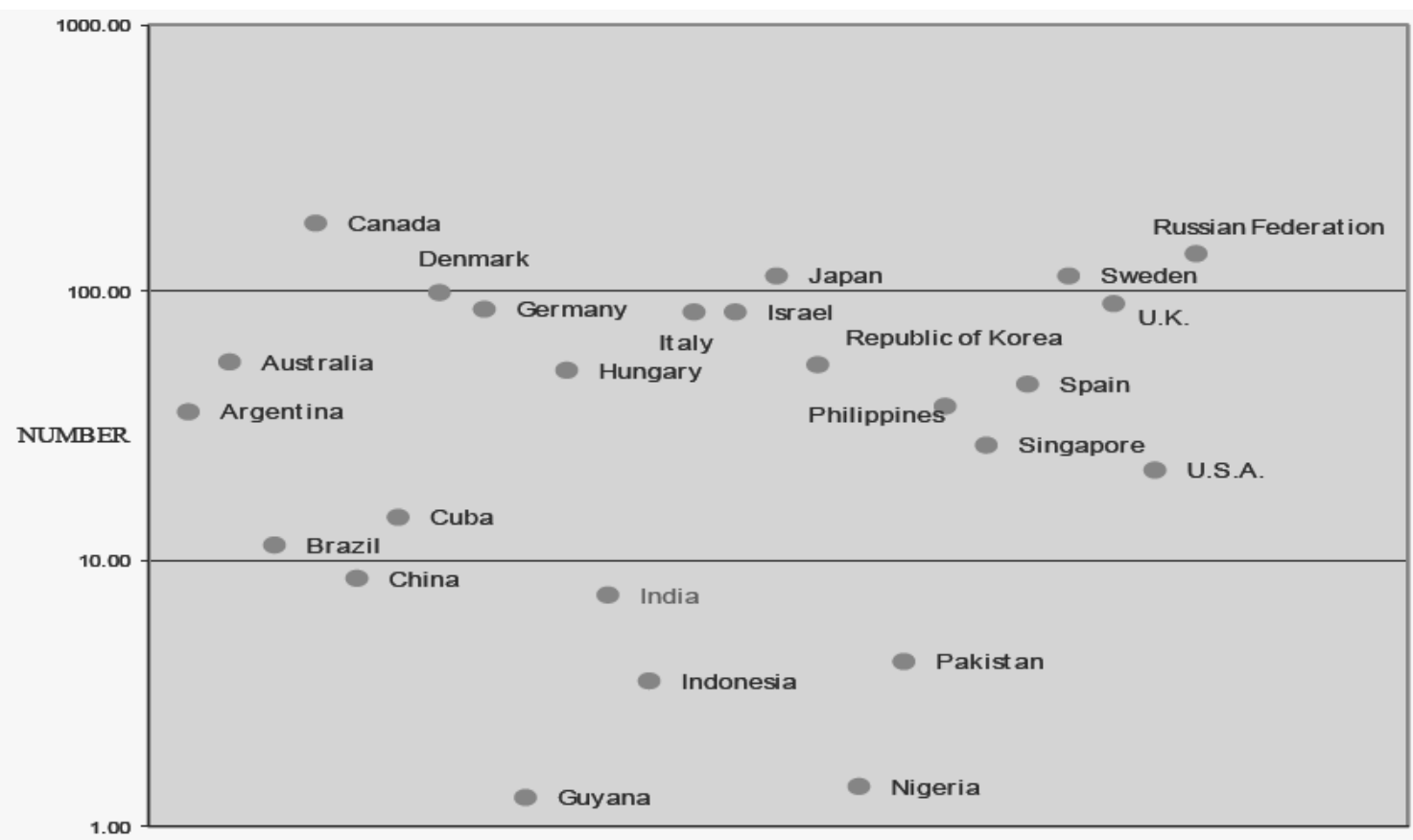

Source: Gol (2005).

Centre for Science and Technology for Development, by 2005 more than 600 multinational corporations, including Motorola, Siemens, IBM, Intel, General Electric and Nokia, had established R\&D laboratories in China (EDS 2005). Although most of the $\mathrm{R} \& \mathrm{D}$ is, in fact, development to tailor products to the needs of the Chinese market, there is some work on the more basic R\&D, such as the Microsoft Research Centre set up in 1998 to take advantage of the China's R\&D skilled labour. According to Richard F. Rashid, the senior vice president of Microsoft Research, 'China was really the No. 1 target from the beginning. We felt there was a tremendously deep pool of talent' (The New York Times 2004). Similarly, many multinationals have set up R\&D laboratories in India, as for example, General Electric in the John. F. Welch Technology Centre in Bangalore, which in 2000 was their largest single R\&D location outside the US. The ultimate reason for the relocation of multinationals to India and China is the high return on R\&D investment, realized through the skilled R\&D workers. Mr Welch, the then chief operating officer of General Electric, commented 'India is a developing country, but it is developed country as far as its intellectual infrastructure is concerned. We get the highest intellectual capital per dollar here' (Tripathi 2007).

\section{The role of the government}

\subsection{China}

\section{Transforming national innovation system (NIS)}

In parallel with the economic reform, the Chinese government has been actively involved in setting up technology policies for industrial development since the 1980s. The first step was reforming the Soviet model for innovation system that China had applied since the 1950s. China's national innovation system (NIS) prior to the 1980s 
had been characterized by the complete separation of science and technology (S\&T) activities in public research institutes and manufacturing activities at state-owned enterprises (Xue 1997). The NIS reform focused on the integration of these two sectors by expanding the functions of each, i.e., introducing proper systems of innovation for both the science and industrial sectors (Liu and White 2001).

The Chinese government pushed the $\mathrm{R} \& \mathrm{D}$ institutes to adapt to the market environment and to become more involved with R\&D that had industrial implications. To initiate the process, the government reduced institutional funding for public research institutes (PRIs) and universities (Motohashi and Yun 2007). The government also undertook a three-step procedure: (i) advocating in 1987 the merger of some R\&D institutes with enterprises; (ii) offering as of 1988 encouragement and financial incentives for the commercialization of $R \& D$ results, especially through the Torch Programme; and (iii) starting in the 1990s to reform the established R\&D institutes into entities that, as production and consultancy centres, could also incorporate economic functions (Gu 1999; Fan 2006a; Fan and Watanabe 2006).

On the other hand, enterprises, not only state-owned enterprises, but also multinational corporations (MNCs) and new tech enterprises, became involved in the NIS and started to conduct more R\&D. As a result, the business sector (large- and medium-sized enterprises) rose to become a major spender of national R\&D, spending in 2001 for instance RMB 44 billion, an increase of RMB 14 billion from the 1995 level and accounting for 42 per cent of the national total (Fan and Watanabe 2006). According to the $R \& D$ Magazine (2005), in $2004 \mathrm{R} \& D$ spending by the industry sector accounted for 61.2 per cent of the national total.

Nevertheless, it has to be realized that China's road to reform was not smooth. The initial NIS reform policy, merging $R \& D$ institutes with existing enterprises, was a failure because of the lack of financial resources from the enterprises supporting the $R \& D$ institutes and the mismatch between the technology development needs of the enterprises and the research institutes (Fan and Watanabe 2006).

\section{Development of technology policy initiatives}

In conjunction with transforming the NIS, the government also put in place a series of technology policy initiatives. Among the principal components are Key Technologies Research and Development Programme, High-tech Research and Development Programme (Programme 863), and the National Programme for Priority Basic Research and Development (Programme 973) (Table 2).

China's first and largest scientific and technological plan in the reform era was the Key Technologies Research and Development Programme, initiated in 1982. The aim of the programme was to find solutions to key technological issues related to national economic and social development, covering the fields of agriculture, electronic information, energy resources, transportation, materials, resource exploration, environmental protection, medical and health care, etc. Tens of thousands of individuals from more than thousand scientific research institutes nationwide participated in the programme, making it the largest national S\&T plan with respect to funds invested and personnel (China Net 2007). 
Table 2

Major technology policy initiatives in China since the reform

\begin{tabular}{ll}
\hline Year & Policy initiative \\
\hline 1982 & - Key Technologies Research and Development Programme \\
1986 & - High-tech Research and Development Programme (Programme 863) \\
1988 & - Torch Programme \\
1991 & - The first high-tech park (Zhongguancun High-tech Park) was established \\
1990 & - First group of 27 high-tech parks was set up. \\
1995 & - Decision on accelerating S\&T development was announced by the State Council \\
1997 & - National Programme for Priority Basic Research and Development ( Programme 973) \\
\hline
\end{tabular}

Source: Compiled by the author.

The objective of High-tech Research and Development Plan or Programme 863 was to promote high-quality fundamental research in China with a specific focus on eight areas (biotechnology, aero-space, information, laser, automation, energy resources, new materials and oceanology) and 20 subjects that were critical to the country's technology and industrial development. Experienced scientists and researchers are selected for the project and the participation of domestic firms is also welcomed. The rationale of plan 863 is that this basic research is critical for China's national technological competitiveness, but too costly to conduct at individual research units or firms (GoC 2007a).

Complementary to the previous two programmes which focus on fundamental research, the Torch Programme was initiated in 1988 to facilitate market-oriented technological development and commercialization of technology. It is the most important high-tech industrial development plan in China The Torch Programme's objectives include (i) developing a favourable environment for high-tech industry; (ii) setting up high-tech zones and start-up service centres for high-tech businesses; (iii) executing industrial projects in areas identified by Plan 863; (iv) facilitating international cooperation of Chinese high-tech firms; and (v) training high-quality human capital (GoC 2007b).

One particular goal of the Torch Programme was to set up high-tech parks specializing in high-tech innovation, application, and diffusion to attract foreign high-tech multinational corporations and to encourage the development of domestic innovative companies. Since the establishment of Zhongguancun Science Park in May 1988, hightech parks designated by the national government have developed into major locations for the country's high-tech industries. By 2003, China had about 33,392 high-tech enterprises, with 67 per cent of these located in high-tech parks. The average annual growth rate of the number of firms, their total employment, total revenue, and export value from 1991 to 2004 reached 25 per cent, 31 per cent, 41 per cent and 52 per cent, respectively (Fan 2006b)

On 5 May 1995, the state council announced the 'Decision on Accelerating S\&T Development' which outlined plans for China's scientific and technology development for the next several decades and emphasized that S\&T research should be closely linked to the market. One ambitious goal of the Decision was to increase by 2000 China was spending on R\&D to 1.5 per cent of GDP when at the time the corresponding figure was only 0.6 per cent of GDP. China's R\&D expenditure as a percentage of GDP has grown at a faster pace after1995 than in previous years and reached 1.44 per cent in 2006. The significant contribution of technological progress to economic growth in the second half 
of the 1990s is obviously closely related to the country's determination to develop its innovation capability.

In June 1997, the Chinese government approved the National Programme for Priority Basic Research and Development (Programme 973) to strengthen indigenous innovation and to target innovation related to sustainable development to such areas as agriculture, energy, information, resources and environment, population and health and materials. The programme involved two development strategies: to 'rejuvenate the country through science and technology' and 'sustainable development' (GoC 2007c). The four main tasks of the programme include: (i) conducting multi-disciplinary integrated research and providing theoretic and scientific foundation for important scientific issues in the fields listed above; (ii) deploying relevant, important and explorative forefront basic research; (iii) nurturing highly qualified human resources in scientific fields; and (iv) setting up a number of high-level national research bases and multi-disciplinary research centres.

Based on earlier reforms of the innovation system, China's fifteenth 5-year plan (2001-05) further articulated its central theme in the new millennium-economic development driven by technological progress, once again, emphasizing that innovation activities are to be further promoted.

\subsection{India}

The government of India has always promoted the development of indigenous technologies. It built up an extensive network of science and technology institutions, and granted tax incentives for the R\&D efforts of enterprises. Recently, programmes have been organized on technology management to advise enterprises on technology forecasting and assessment as well as market evaluation (Katrak 2002).

\section{Transforming NIS}

Similarly to China, the Indian government has taken a series of steps to modernize its NIS, starting from the 1980s when economic reform took place. India had a highly restrictive regime until the mid-1980s, characterized by protection of its domestic firms from both international and internal competitions. Strict industrial licensing for the entry, expansion, and diversification of firms regulated internal competition among domestic firms, while restricted entry and expansion of foreign companies regulated competition between domestic and foreign companies. High tariff rates, import licensing, and quota restrictions protected domestic firms from international competition (Aggarwal 2000)

Deregulation was initiated in the mid-1980s in order to reform the old regime. Abolishment of industrial licensing in a number of industries and trade liberalization 2 increased competition between firms, domestically and internationally. Other important initiatives included exchange rate adjustment by allowing the depreciation of rupee and liberalizing foreign capital and important technologies. The restrictions on technology

2 Trade liberalization measures include reduction in tariff rates, rationalization of tariff structure, relaxation in import licensing requirement, and deregulation of imports of raw materials, components and capital goods (Aggarwal 2000). 
imports were relaxed substantially through measures such as the mitigation of sectoral restrictions on technology imports, substantial tax cuts on royalties and technical fees, simplification of tax structure, and deregulation of imports of drawings and designs (Aggarwal 2000; Katrak 2002)

In tandem with the change to a more liberalized regime, one dimension of India's NIS transformation was the reform of its industrial research institutes (IRIs), which had been set up by the government to promote indigenous technological knowhow and to help enterprises introduce new products and procedures. Even though the economic rational had been to gap the bridge caused by 'market failure',3 India's IRIs performed poorly in the face of problems relating to finance, uncertainty and other issues. Furthermore, user enterprises lacked the capability to assimilate with the technology of the IRIs. Another contributing factor to the poor performance of the IRIs could have been their institutional arrangement, which may have been affected with an 'ivory tower' attitude: scientists, engineers and technologists concentrated on technological projects which would bring them peer recognition but which had only limited commercial use. In addition, the IRIs have become ineffective because of inefficient use of resources (Katrak 1998)

The government ended the traditional R\&D policy according to which subsidies and grants for R\&D were the principal public support mechanism. National laboratories of the Council of Scientific and Industrial Research (CSIR) and other prestigious technical institutes were instructed to earn at least 30-50 per cent of their R\&D expenditures through the commercialization of indigenously developed technologies and the generation and utilization of patents (Sikka 1998). The 1997-98 budget proposed that R\&D institutions recognized by the Department of Science and Technology be allowed to retain equity holdings in the private enterprises that used their technology (Katrak 1998).

\section{Development of technology policies}

Indian government has a long history of encouraging technology development. Before reform, the focus was on creating a strong technological infrastructure and providing human resources to research communities and industries. By 1998, India had about 3,000 scientific institutions, with 2,000 devoted to R\&D (including in-house research and development units of industrial sector, academic institutions, test laboratories and technology centres) (Kumar and Jain 2003). The first key initiative was the Scientific Policy Resolution enacted in 1958 to support early and critical stages of industrialization. The next milestone was the Indian Patents Act of 1970, which granted patents for the specific processes of products rather than the products themselves. The Act created the opportunity for Indian firms to adapt reverse engineering for optimal processes and thus boosted their R\&D capability. The Act was amended in 1999 and subsequently made TRIPS4 compliant in 2003 (Mani 2004).

3 Enterprises, especially small- and medium-sized ones, may not have sufficient financial resources to cover the large costs involved in technological efforts; they may also be discouraged by the uncertainty; and they may not be able to fully capture the benefits of the R\&D efforts (Katrak 1998).

4 TRIPS is the acronym for Agreement on Trade-related Aspects of Intellectual Property Rights, an international agreement administrated by World Trade Organization (WTO). 
One important moderation was the provision of venture capital funds. The Technology Policy Statement (1983), Research and Development Cess Act (1986), and Technology Development Board Act (1995) were enacted to provide risk-sharing funds and managerial expertise for technology development and commercialization. The Technology Policy Statement (TPS) of 1983 was a new initiative in the reform era, aiming at increasing technological competence and self-reliance in strategic areas. While special emphasis is given to indigenous technology, the TPS also advocates a mix of indigenous and imported technology (Kumar and Jain 2002).

The Research and Development (R\&D) Cess Act of 1986 established a fund for the import of technologies, to finance development of indigenous technologies, and to make imported technologies indigenous. In addition to the R\&D Cess Act, some resources are also provided through venture capital funds and a few other schemes, such as the Technology Information and Forecasting Assessment Council (TIFAC) established in 1988 under the Home Grown Technology scheme. The autonomous body of the government of India also provides some financing and facilitates the development and commercialization of technologies. The Technology Development Board Act (1995) was another policy initiative in that direction (Kumar and Jain 2002).

Other schemes to facilitate and promote technology testing, up-scaling, and commercialization include the Programme Aimed at Technological Self-Reliance, The Sponsored Research and Developments Scheme, and the Programme for Acceleration of Commercial Energy Research, etc. (Kumar and Jain 2003).

The government announced a new S\&T policy in 2003 which ambitiously set the goal of R\&D spending at 2 per cent of GDP by March 2007. The policy articulated eleven strategies for achieving the objective and, compared to its predecessors, the policy also had four new features: (i) it recognized that India has a large pool of scientists and engineers, but a low density; (ii) it acknowledged the necessity of managing the braindrain from the country; (iii) it highlighted the trend of increasing patenting both at home and abroad, and (iv) it noted the need to monitor implementation of the policy. Despite the aggressive goal, the feasibility of implementing the policy has been questioned (Mani 2004).

Table 3

Major technology policy initiatives in India

\begin{tabular}{ll}
\hline Year & Policy initiative \\
\hline 1958 & - Scientific Policy Resolution \\
1970 & - Indian Patent Act \\
1983 & - Technology Policy Statement (new draft announced in 1993, but not adopted) \\
1986 & - Research and Development Cess Act \\
1988 & - Announcement of the Venture Capital Guidelines \\
1995 & - Technology Development Board Act \\
1996 & - Announcement of CSIR 2001: Vision and Strategy \\
& - Securities and Exchange Board of India (Venture Capital Funds) Regulations 1996 \\
1999 & - Amendment of the Indian Patents Act 1970 \\
2000 & - Announcement of New Millennium Indian Technology Leadership \\
2003 & - New S\&T Policy
\end{tabular}

Source: Mani (2004). 


\section{Innovation capability development of domestic companies}

Biotech industry, along with information technology, can be an appropriate field for examining the relationship between the innovation capability and economic growth of a nation. Constituting one of the three essential technologies of the knowledge economy (information technology, biotechnology and nano technology), the biotech industry and its revenue have grown rapidly, reaching US\$60 billion in 2006, or ten times its 1996 level (Nature Biotechnology 2006). The innovation intensity of the biotech industry is reflected in the fact that it is one of the most $R \& D$ intensive industries. In 2002, global leaders of the biotech industry spent an average of more than 20 per cent of their revenue on $R \& D$, whereas computer hardware and software fields spent, on average, less than 10 per cent and 20 per cent, respectively (MIT 2003). Corresponding to heavy investment, biotechnology is also one of the innovative-intensive emerging industries.

Similarly to their success in the ICT industry (China focusing on ICT hardware and India on ICT software), these two giants have within short timespan successfully proven themselves as world players in the biotech industry. Over the 2000-05 period China achieved within this specialized field an annual growth rate of 30 per cent, while India achieved a growth rate of 36 per cent during 2005-06 (Jia 2006c; Biospectrum 2006a). In 2006, China and India ranked in 9th position and 11th position, respectively, in biotech revenue (Buckley et al. 2006).

It is worth mentioning that innovative domestic companies are essential for the expansion of the biotech industry in both countries. During 2005-06, 14 of India's top 20 biotech firms were 'home-grown' and all top six companies domestic. Moreover, India is quite advanced in globalizing their revenue; the country's biotech industry obtained more than 50 per cent of its revenue from the international market during the same period (Biospectrum 2006a)

\subsection{Selected domestic companies and their innovation capability}

Based on my research of biopharmaceutical industries in China and India, I have selected three companies from each country to illustrate the importance of innovation capability in the development of domestic companies.

The three selected Chinese companies were established in the late 1990s and are located on the east coast (Table 4A). SiBiono became the first company in the world to produce a license gene therapy drug in 2003. The gene therapy, recombinant Ad-p53 anti-cancer injection, is registered under the brand name Gendicine, targets squamous cell carcinoma (HNSCC) of the head and neck. Sunway's H100 Series targets the same disease. Currently, HNSCC is the second most common type of cancer in China, with about 2.5 million new patients every year, accounting for 10 per cent of all cancer patients. MedGenn's main innovation is Endostar, recombinant human endostatin for non-small cell lung cancer (China Daily 2004; Jia 2006a).

The three innovative Indian domestic firms-Shantha Biotechnics, Bharat Biotech International, and Jupiter Biotechnology—are all located in Hyderabad, the bio-valley of India. Shantha Biotechnics and Bharat Biotech International are acknowledged as dedicated and innovative biopharmaceutical startup companies that have managed to gain significant success and recognition (Frew et al. 2007). As Table 4 illustrates, 
innovation capability of the Indian firms is primarily demonstrated by a large number of their own brands of recombinant products. For instance, Shantha was the first in India to develop the r-DNA hepatitis B vaccine, followed by Bharat and others. Both Shantha and Bharat have a range of recombinant products based on their own innovations. Jupiter, on the other hand, is the leading world producer in drug intermediates.

Examination of domestic medical biotech companies indicates that India has currently outperformed China in terms of quantity, scale of manufacturing, and globalization. Apparently firms in these two countries have very different development paths. Domestic companies in India started with products that were already produced by multinational corporations and began to build manufacturing parallels, thus improving their R\&D capability. Chinese companies, on the other hand, collected ideas dropped by the US start-up companies and leapfrogged to first position in the sector. Despite the differences, both governments have provided crucial stimuli to starting-up these innovative companies.

Table 4

Innovative domestic medical biotech companies in China and India

\begin{tabular}{|c|c|c|c|}
\hline \multicolumn{3}{|c|}{ Established Location } & Main innovations \\
\hline \multicolumn{4}{|l|}{ CHINA } \\
\hline $\begin{array}{l}\text { Shenzhen SiBiono GeneTech } \\
\text { Co. Ltd (SiBiono) }\end{array}$ & 1998 & Shenzhen & $\begin{array}{l}\text { Gendicine (recombinant adenovirus type } 5 \text { gene } \\
\text { therapy carry human p53 gene) for head and neck } \\
\text { cancer squamous-cell carcinoma: first gene therapy } \\
\text { in the world }\end{array}$ \\
\hline \multirow[t]{2}{*}{$\begin{array}{l}\text { Yantai MedGenn Co. Ltd } \\
\text { (MedGenn) }\end{array}$} & 1999 & $\begin{array}{l}\text { Yantai, } \\
\text { Shandong }\end{array}$ & $\begin{array}{l}\text { Endostar (recombinant human endostatin) for non- } \\
\text { small cell lung cancer }\end{array}$ \\
\hline & & & $\begin{array}{l}\text { Originally developed by Entremed until } 2003 \text {, } \\
\text { endostar has an additional } 9 \text {-amino acid sequence at } \\
\mathrm{N} \text { terminus }\end{array}$ \\
\hline \multirow{3}{*}{$\begin{array}{l}\text { Shanghai Sunway Biotech } \\
\text { Co. Ltd (Sunway) }\end{array}$} & 1995 & Shanghai & H 100 Series \\
\hline & & & $\begin{array}{l}\text { H101: (recombinant oncolytic adenovirus type } 5 \text { ) for } \\
\text { head and neck cancer squamous-cell carcinoma }\end{array}$ \\
\hline & & & $\begin{array}{l}\text { H101: a modified version of Onyx-015 } \\
\text { Note: originally developed by Onyx Pharm. and later } \\
\text { abandoned }\end{array}$ \\
\hline
\end{tabular}

\begin{tabular}{|c|c|c|c|}
\hline \multicolumn{4}{|l|}{ INDIA } \\
\hline Shantha Biotechnics & 1993 & Hyderabad & $\begin{array}{l}\text { r-DNA hepatitis B vaccine (first in India), } \\
\text { erythropoietin, streptokinase, oncology segment } \\
\text { More than half of revenue from exports }\end{array}$ \\
\hline Bharat Biotech International & 1996 & Hyderabad & $\begin{array}{l}\text { r-DNA hepatitis B vaccine, streptokinase (first in } \\
\text { India), typhoid vaccine, vaccines for malaria and } \\
\text { rotavirus infection. } \\
\text { More than half of revenue from exports }\end{array}$ \\
\hline Jupiter Bioscience Limited & 1985 & Hyderabad & $\begin{array}{l}\text { Leading player in drug intermediates, especially } \\
\text { peptide, one of the top } 5 \text { global players (only one in } \\
\text { Asia) } \\
\text { Most revenue come from exports }\end{array}$ \\
\hline
\end{tabular}

Sources: Jia (2006a) for China; compiled by author for India. 


\subsection{Innovation capability}

The findings of domestic biotech firms in terms of innovation capability can be summarized as following:

First, innovation capability has become more and more vital to the success of the Chinese and Indian biotech firms. Successful firms introduced branded products to the market through their innovation, as illustrated in Table 4. By 2006, the Indian government had approved 14 recombinant biotech products, seven of which were developed and are currently manufactured by Indian firms: hepatitis B vaccine, streptokinase, human insulin, granulocyte colony stimulating factor (G-CSF), erythropoietin, human growth hormone and interferon alpha 2b (DBT 2006b). Further, faced with declining profits (price wars), traditional pharmaceutical firms are looking into innovation as an alternative. For instance, India's pharmaceutical companies have entered the bio-drug field, such as Biocon and Dr Reddy's. China lags behind India in this issue, and traditional pharmaceutical companies need to seek for options to overcome their present predicament, for example, through the purchase of small innovative biotech companies.

Second, institutional factors have great influence over the choice of innovation at the firm level, i.e., the decision at firm level in terms of indigenous R\&D or the import of technology. The change in the intellectual property (IP) regime has provided a certain push for the domestic firms to move towards indigenous R\&D. With the implementation of WTO-GATT Agreement in 2005, the Indian firms' conventional manufacturing procedures based reverse engineering are being challenged because they are effectively barred from replicating innovations patented in the western world (Mani 2004). On the other hand, India has become a signatory to the Patent Cooperation Treaty, administered by the WIPO, making it easier for India to file a patent protecting IP rights. Similarly, China's membership in the WTO and signing of the TRIPS imply that the country needs more indigenous $R \& D$ than innovations based on duplication or reverse-engineered versions of western patents. Further, the push by both governments has provided incentives and encouraged domestic companies to innovate, as exemplified by India's department of biotechnology established in 1986 to provide a better environment for biotech development, technology transfer between research institutes and private companies, etc. On the other hand, China's National Development and Reform Commission (NDRC) provides financial guidelines. For instance, the Guideline on Pharmaceutical Industry Development for the 11th Five-Year Period (2006-2010) released on 4 September 2006 proposed that both public and private money earmarked for pharmaceutical R\&D be increased from the current 1 per cent to 3 per cent of revenue from pharmaceutical sales by the end of 2010. In anticipation that large pharmaceutical groups would invest in biotech research, the guideline also outlined greater pricing leeway to producers of innovative drugs, whereas the NDRC had earlier forced pharmaceutical firms to slash their prices (DBT 2006a; Jia 2006b, 2006c)

Nevertheless, two major challenges face both China and India in the development of innovation capability through biotech industry: financial and human resources constraints.

Limited financial resources have become the bottleneck in both countries in the development of biotech industry. Currently, government support has been the main avenue of financing domestic firms in China and India, especially for start up firms, 
although Indian firms are more advanced in manufacturing and are thus able to channel a quite significant portion of the revenue back to $R \& D$. For instance, the three Chinese firms selected for this study relied heavily on financial support from the government. Even though venture capital (VC) or private equity (PE) is increasingly an option, their contribution is quite insignificant in both countries. In China biotech VCs are mainly created by governments and strict regulations discourage international VCs from entering the market. Nevertheless, other financing alternatives should be examined. Indian domestic companies have actively sought international funding sources, ranging from venture capital, to international organizations such as the World Bank and the IMF, and to philanthropic organizations such as the Bill and Melinda Gates Foundation (Biospectrum 2006b, 2006c).

The second major hindrance to the biotech industry of the two giants relates to mediocre qualifications of human resources. Even though both countries have a good education infrastructure and a large pool of low-cost scientists, university education cannot meet the standards of the industry. To rectify the situation, India's DBT's human resource plan has proposed various approaches for a quick fix of qualified biotech graduates, post-graduate doctors, and scientists (DBT 2006a). China, compared to India, needs in particular manufacturing technicians (Jia 2007). Both countries are looking to attracting expatriates from overseas into high-level elite positions in the hope of repeating Taiwan's success story in the electronics industry.

\section{Conclusion}

Both China and India, as the emerging giants in Asia, have achieved significant economic development in recent years. China has enjoyed a high annual GDP growth rate of 10 per cent and India has achieved an annual GDP growth rate of 6 per cent since 1981. As innovation capability is vital in the development of today's knowledge economy, I have evaluated its contribution to economic growth in China and India.

Decomposing China and India's GDP growth from 1981 to 2004 into the contribution of the three factors reveals that technology has contributed significantly to both countries' GDP's growth, especially in the 1990s. However, from 2001-04, the contribution from technology progress to economic development in India diminished to a marginal position. Rapid growth of high-tech exports, service exports, and certified patents from United States Patent and Trademark Office (USPTO) further attest to the fact that the innovation systems in both countries have, over the reform years, increased their output efficiency. It should also be noted that the countries invested heavily in knowledge inputs such as R\&D expenditures and R\&D human resources, particularly China with respect to $R \& D$ expenditure. The business sector's increased share in $R \& D$ expenditures indicates that enterprises have become the main actor in $R \& D$ in China, whereas India's R\&D is still dominated by public research institutes.

Both governments have played an essential role in transforming their national innovation systems to become more adaptable to economic development, and one of main focus of $R \& D$ reforms was to integrate the science and business sectors and to provide incentives for innovation activities. Balancing the import of technology with indigenous $R \& D$ effort was another major theme. 
Finally, the paper concludes with a review of the development of the biotech industry in both countries, with special focus on the progress of innovation capability of domestic firms - a factor that is becoming more and more critical to the success of the Indian and Chinese biotech firms. Institutional factors have great influence over the choice of innovation at the firm level, i.e., the decision at firm level in terms of indigenous R\&D or the import of technology. But limited financial resources and the mediocre human resource qualifications remain two major challenges for domestic companies in both China and India.

\section{References}

Aggarwal, A. (2000). 'Deregulation, Technology Imports and In-house R\&D Efforts: An Analysis of the Indian Experience'. Research Policy, 29: 1081-93.

Asia News (2004). 'China's High Tech Exports; 2004'. Available from: www//asia.news.yahoo.com/040106/afp/040106182907hightech.html.

BioSpectrum (2006a). ‘A Good Year Again’. BioSpectrum, 4 (6): 22-9.

BioSpectrum (2006b). 'Biofunds, Still Elusive’. BioSpectrum,4 (9): 26-7.

BioSpectrum (2006c). 'VC and Private Equity Investment'. BioSpectrum, 4 (9): 28.

Buckley, J. G., M. Tang, H. Thorsteinsdottir, A. Gupta, S. Louet, M.C. Shin, and M. Wilson (2006). 'The Beaten Path'. Nature Biotechnology, 24 (3): 309-15.

China Daily (2004). ‘Chinese Firm Develops Gene Therapy Injection’. China Daily.

China Daily (2007). 'China's GDP Grows 10.7\% in 2006, Fastest in 11 Years'. 26 January. Available at: www.chinadaily.com.cn/china/2007-01/26/content_ 793128.htm

China Gate (2006). 'Chinese R\&D Spending Soon 2nd Worldwide'. Available at: www.chinagate.com.cn/english/science/49448.htm

China Net (2003). 'China Ranks 3rd in R\&D Spending: OECD Report'. Available at: www.china.org.cn/english/BAT/78987.htm

China Net (2007). State Programmes for the Development of Science and Technology'. Available at: www.china.org.cn/english/zhuanti/china2003/73502.htm

Collins, S. M., and B. Bosworth (1996). 'Economic Growth in East Asia: Accumulation Versus Assimilation’. Brookings Papers on Economic Activity, 2: 135-204.

Dahlman, C. (1994). 'Technology Strategy in East Asian Developing Economies'. Journal of Asian Economics, 5: 541-72.

DBT (Department of Biotechnology) (2006a). 'DBT Annual Report 2005-2006'. New Delhi: DBT, Ministry of Science and Technology, Government of India.

DBT (2006b). India Biotechnology Handbook 2006. New Delhi: DBT, Ministry of Science and Technology, Government of India.

Department of Science and Technology, Government of India, 2005. National Presentation: India, on Science and Technology Statistics. UNESCO South Asian Regional Workshop. New Delhi, 2005.

(The) Economist (2007). 'Fact Sheet on India'. Available at: www.economist.com/countries/India/profile.cfm?folder=Profile-FactSheet 
EDS (Electronics Design, Strategy, News) (2005). 'Is China the Next R\&D Superpower?’. Available: www.edn.com/article/CA610433.html

Fan, P. (2006a) 'Promoting Indigenous Capability: The Chinese Government and the Catching-up of Domestic Telecom-Equipment Firms’. China Review, 6 (1): 9-35.

Fan, P. (2006b). 'Comparative Analysis of High-tech Parks in Beijing and Shanghai'. Journal of Nanjing University (Nature Science), 42 (3): 242-56.

Fan, P., and C. Watanabe (2006). 'Promoting Industrial Development through Technology Policy: Lessons from Japan and China’. Technology in Society, 28 (3): 303-20.

Frew, S., R. Rezaie, S. M. Sammut, M. Ray, A. S. Daar, and P. A. Singer (2007). 'India's Health Biotech Sector at Crossroads'. Nature Biotechnology, 25 (4): 403-17.

GoC (Government of China) (2007a). 'Programme 863: High-tech Research and Development Plan of China'. Beijing: Government of China. Available at: www.863.org.cn/ (in Chinese).

GoC (Government of China) (2007b). 'China Torch Programme'. Available at: www.ctp.gov.cn (in Chinese).

GoC (Government of China) (2007c). 'National Basic Research Programme of China'. Available at: www.973.gov.cn (in Chinese).

GoI (Government of India) (2006). Major Highlights. Delhi: Department of Science and Technology, Government of India. Available at: dst.gov.in/majorhighlights.pdf

GoI (Government of India) (2005). 'National Presentation: India, on Science and Technology Statistics'. Presented by the Department of Science and Technology at the UNESCO South Asian Regional Workshop. New Delhi.

Gu, S. (1999). 'China’s Industrial Technology’. Tokyo: United Nations University Press.

Hobday, M. (1995). Innovation in East Asia. New York: Edward Elgar Publishing Ltd.

Jia, H. (2006a). 'China Offers Alternative Gateway for Experimental Drugs'. Nature Biotechnology, 24 (2): 117-8.

Jia, H. (2006b). 'China Kick-starts its Vaccine Market'. Nature Biotechnology, 24 (4): 375.

Jia, H. (2006c). 'Poor Enforcement Could Jeopardize China’s Drug Innovation Policy'. Nature Biotechnology, 24 (10): 1182-3.

Jia, H. (2007). 'Chinese Biotech Hamstrung by Production Issues'. Nature Biotechnology, 25 (2): 147-8.

Katrak, H. (1998). 'Economic Analysis of Industrial Research Institutes in Developing Countries: The Indian Experience’. Research Policy, 27: 337-47.

Katrak, H. (2002). 'Does Economic Liberalization Endanger Indigenous Technological Developments? An Analysis of the Indian Experience'. Research Policy, 31: 19-30.

Kim, L. (1998). From Imitation to Innovation: Dynamics of Korea's Technological Learning. Boston: Harvard Business School Press.

Krugman, P. (1994). 'The Myth of the Asian Miracle'. Foreign Affairs, NovemberDecember. 
Kumar, V., and P. K. Jain (2002). 'Commercializing New Technologies in India: A Perspective on Policy Initiatives’. Technology in Society, 24 (3): 285-98.

Kumar, V., and P. K. Jain (2003). 'Commercialization of New Technologies in India: An Empirical Study of Perceptions of Technology Institutions’. Technovation, 23 (2): $113-20$.

Lal, D. (1995). 'India and China: Contrasts in Economic Liberalization'. World Development, 23 (9): 1475-94.

Liu, X., and S. White (2001). 'Comparing Innovation Systems: a Framework and Application to China’s Transition Context’. Research Policy, 30, 1091-114.

Mani, S. (2004). 'Institutional Support for Investment in Domestic Technologies: An Analysis of the Role of Government in India'. Technological Forecasting and Social Change, 71 (8): 855-63.

MIT Technology Review (2003). 'The Corporate R\&D Scoreboard 2002'. Cambridge, MA: MIT.

Mahmood, I. P., and J. Singh (2003). 'Technological Dynamism in Asia'. Research Policy, 32: 1031-54.

Motohashi, K., and X. Yun (2007). 'China's Innovation System Reform and Growing Industry and Science Linkages'. Research Policy, 36: 1431-42. Available at: doi:10.1016/j.respol.2007.02.023

Nature Biotechnology (2006). 'The Responsibilities of Growing Up'. Nature Biotechnology, 24 (3): 225.

Nelson, R. (1993). National Systems of Innovation: A Comparative Study. New York: Oxford University Press.

(The) New York Times (2004). 'Let a Thousand Ideas Flower: China is a New Hotbed of Research'. 13 September.

Porter, M. E. (1990). The Competitive Advantage of Nations. New York: Free Press.

$R \& D$ Magazine (2005). 'The State of Global R\&D'. September.

Sikka, P. (1998). 'Analysis of In-house R\&D Centres of Innovative Firms in India'. Research Policy, 27: 429-33.

Tripathi, S. (2007). 'India's Growth Path Steady but not Straight'. Issues in Science and Technology, Spring. Available at: findarticles.com/p/articles/mi_qa3622/is_200704/ ai_n19198509.

World Bank (2004 and 2006). World Development Indicators, CD-Rom. Washington, DC: World Bank.

Xue, L. (1997). ‘A Historical Perspective of China's Innovation System Reform: A Case Study’. Journal of Engineering and Technology Management, 14: 67-81.

Young, A. (1995). 'The Tyranny of Numbers: Confronting the Statistical Realities of the East Asian Growth Experience'. Quarterly Journal of Economics, 110 (3): 64180 . 